\title{
RENAL LESIONS IN CHILDREN WITH ERYTHEMA NODOSUM
}

\author{
BY \\ ARVID WALLGREN, M.D. \\ (From the Children's Hospital, Gothenburg, Sweden)
}

Some years ago I had the opportunity of observing three children with erythema nodosum, in whom an acute haemorrhagic nephritis appeared simultaneously with the skin eruption. All three children were tuberculin sensitive, and in our opinion the tuberculous infection directly or indirectly played a part in the occurrence of the erythema nodosum. In one of the cases a pronounced primary pulmonary tuberculosis was present at the same time.

This simultaneous manifestation of erythema nodosum and haemorrhagic nephritis gave rise to a discussion as to the possibility of there being a connexion between these two manifestations of disease. We did not believe that one affection had produced the other, but took into account the possibility that both affections might be due to a common cause. In Scandinavia we consider erythema nodosum to be an allergic manifestation of disease, and haemorrhagic nephritis is by many workers also classed among the allergic phenomena. I shall not here enter into a discussion of this point of view.

Now haemorrhagic nephritis is the clinical manifestation of a series of renal changes, decreasing in intensity, in which there are subclinical transitions to normal conditions. Recent investigations have shown that some of the morphological elements occurring in a nephritic urine, especially red blood corpuscles and casts, may even normally be excreted in the urine. Quantitative tests by Addis's method have made it possible to fix the boundary-line between the physiological and pathological conditions in this respect.

Assuming that subclinical renal changes in erythema nodosum might be much more common than can be gathered from the limited number of clinically obvious cases of haemorrhagic nephritis (three cases of nephritis among more than eight hundred cases of erythema nodosum), the urine of eighty-eight children with erythema nodosum was examined by the Addis method. We considered, in order to be on the safe side, the upper normal limit of erythrocyte excretion to be at most 500,000 in twelve hours. The results are shown in the following tables :- 
TABLE 1

\begin{tabular}{|c|c|c|c|c|c|c|c|c|c|c|c|c|c|c|}
\hline \multirow[b]{2}{*}{$\begin{array}{l}\text { No. of red } \\
\text { blood cor- } \\
\text { puscles in } \\
\text { thousands } \\
\text { per } 12 \text { hours }\end{array}$} & \multicolumn{6}{|c|}{ NORMAL } & \multicolumn{8}{|c|}{ PATHOLOGICAL } \\
\hline & $\frac{8}{1}$ & ஓ्: & ষ্ণ & 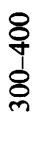 & $\begin{array}{l}8 \\
\stackrel{1}{1} \\
8 \\
8\end{array}$ & & $\begin{array}{l}8 \\
\frac{n}{1} \\
\frac{1}{n} \\
n\end{array}$ & $\frac{8}{8}$ & $\frac{8}{\frac{8}{1}}$ & 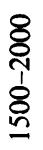 & $\begin{array}{l}8 \\
\text { ర్ల } \\
\delta \\
\delta\end{array}$ & $\begin{array}{l}\text { \& } \\
\text { + } \\
\delta\end{array}$ & $\stackrel{8}{\stackrel{8}{\&}}$ & \\
\hline $\begin{array}{cc}\text { Number } & \text { of } \\
\text { cases } & \ldots\end{array}$ & 23 & 15 & 12 & 8 & 6 & Total 64 & 7 & 6 & 3 & 1 & 1 & 2 & 4 & Total 24 \\
\hline
\end{tabular}

TABLE 2

\begin{tabular}{lll|c|c}
\hline & & & $\begin{array}{c}\text { NORMAL } \\
\text { FINDING }\end{array}$ & $\begin{array}{c}\text { PATHOLOGICAL } \\
\text { FINDING }\end{array}$ \\
\hline Tuberculin + & $\ldots$ & $\ldots$ & 57 & 22 \\
Tuberculin - & $\ldots$ & $\cdots$ & 7 & 2 \\
\hline- & & & 64 & 24 \\
\hline
\end{tabular}

From table 1 it will be seen that a pathological erythrocyturia was demonstrable in about every third or fourth child with erythema nodosum. After the disappearance of the erythema and the accompanying fever the urine finding again became normal. With regard to the examination carried out, special attention may be called to the following two points : (1) The renal lesions occurred also in children who did not display the least evidence of a complicating throat infection (table 3), and (2) they occurred just as often in the tuberculin negative as in the tuberculin positive cases (table 2). There is therefore no reason for assuming either that a tuberculous or that a streptococcal infection is a requisite condition for the occurrence of pathological erythrocyturia.

TABLE 3

\begin{tabular}{|c|c|c|}
\hline & $\begin{array}{l}\text { THROAT INFECTION } \\
\text { DEMONSTRABLE }\end{array}$ & $\begin{array}{l}\text { THROAT INFECTION } \\
\text { NOT DEMONSTRABLE }\end{array}$ \\
\hline 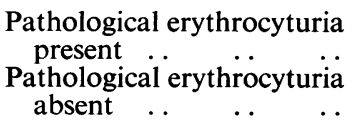 & $\begin{array}{l}18 \\
50\end{array}$ & $\begin{array}{r}5 \\
15\end{array}$ \\
\hline Total .. & 68 & 20 \\
\hline
\end{tabular}

At the same time as Addis counts, capillary fragility tests were made on the children's skin. These tests showed (table 4) that in children with erythema nodosum there is very often a capillary fragility, occasionally very marked, during the erythema nodosum fever. This capillary fragility occurred with 
about the same frequency in children with pathological erythrocyturia as in those in whom this sign was not present. Nor was any relation shown to exist between the occurrence of simultaneous throat infection and the frequency and intensity of capillary fragility among the children with erythema nodosum.

TABLE 4

\begin{tabular}{r|c|c}
\hline & \multicolumn{2}{|c}{ CAPILlARY FRAGILITY TEST } \\
\cline { 2 - 3 } & POSITIVE & NEGATIVE \\
\hline Pathological erythrocyturia present & 7 & 13 \\
Pathological erythrocyturia absent & 18 & 27 \\
\hline Total $\quad . \quad \ldots$ & 25 & 40 \\
\hline
\end{tabular}

Capillary fragility is by no means an unusual phenomenon in the majority of acute and chronic infections. It is thought to be due to a toxically-induced injury to the vascular endothelium. Since it can hardly be assumed that the capillary fragility demonstrated in the erythema nodosum cases depends on a local bacterial action of the agent that provoked the erythematous eruption, it must be concluded that in these cases, too, it is an expression of a toxic injury of the endothelium.

There is therefore good reason for also interpreting the erythrocyturia as an expression of a similar pathological change in the glomerular endothelium. The erythrocyturia in tuberculin positive cases of erythema nodosum is demonstrable only during the febrile stage of the erythema, during which stage the allergic sensitiveness to the tuberculotoxin is exceedingly great. It therefore seems very probable that the action of the toxin on the kidney is also greater during this period. Something similar occurs in all probability in the tuberculin negative cases of erythema nodosum, where the infection provoking the allergictoxic syndrome erythema nodosum also produces capillary fragility of the skin and an endothelial injury to the glomerular endothelium.

\section{Summary}

During the toxic-allergic febrile state induced by various infections, during which erythema nodosum appears there is frequently present evidence of renal lesions, which are usually subclinical but may manifest themselves as an acute haemorrhagic nephritis. These renal lesions are probably to be regarded as an expression of the same toxic or allergic remote action of the infectious agent as that which produced the eruption of erythema nodosum and the capillary fragility of the skin. 


\section{REFERENCES}

Addis, T. A. (1931). Johns Hopk. Hosp. Bull., 49, 203.

Escherich, T., and Schick, B. (1912). Der Scharlach, Vienna.

Friedemann, U., and Deicher, H. (1938). Z Z. klin. Med., 108, 737.

Longcope, W. T. (1929). Johns Hopk. Hosp. Bull., 45, 335.

Lyttle, J. D. (1933). J. clin. Invest., 12, 87, and 95.

Masugi, M., and Isibesi, T. (1935). Virchows Arch., 96, 391.

Nobécourt, P. (1935). Concours Méd., 15.

Wallgren, A. (1938). Lancet, 1, 359. 